\title{
Effect of Cement Kiln Dust on the Geotechnical Properties of Clay in Ede, South-western, Nigeria
}

\author{
Adedokun, S.I., Oluremi, J.R.", Adekilekun, N.T. and Adeola, O.V. \\ Department Civil Engineering, Ladoke Akintola University of Technology, Ogbomoso. Nigeria. \\ *Corresponding author's email: jroluremi@lautech.edu.ng
}

\begin{abstract}
This paper investigated the effect of cement kiln dust (CKD) on the geotechnical properties of clay. Soil sample was collected from clay depositat Ede North Local Government Area, Osun State, which lies within the geographical coordinates of $7{ }^{\circ} N$ and $4^{\circ} E$, was treated with up to $10 \%$ CKD. Sieve analysis, specific gravity, consistency limits, compaction (British Standard Light, BSL and West African Standard, WAS) and California Bearing Ratio (CBR) tests were carried out on both treated and untreated soil samples. Results showed that Ede clay is an A-7- 6 soil. Specific gravity increased from 2.61 to 2.91 with increase in CKD from 0 to $10 \%$, maximum dry density (MDD) of the natural soil sample increased from 1.72 and $1.76 \mathrm{~g} / \mathrm{m}^{3}$ to 1.84 and $1.85 \mathrm{~g} / \mathrm{m}^{3}$ at $8 \%$ CKD for BSL and WAS, respectively. The unsoaked CBR of the specimen increased from 17 to $35 \%$ for $0-10 \%$ addition of CKD, and a similar trend was observed for the 24 hours soaked $C B R$ values. This study indicated that $C K D$, though regarded as waste material, can be used to improve the geotechnical properties of Ede clay.
\end{abstract}

Keywords: Cement kiln dust, Compaction, California bearing ratio. clay, Recycled waste material,

\section{Introduction}

The engineering properties of soil can be improved with the reuse of waste products from several industrial wastes. Large amount of by-products with some good engineering properties are produced from industries and are mostly dumped as waste into the environment. Reusing these waste products will conserve natural resources and save valuable landfill space. The major waste management method, which has received the attention of environmental researchers, is the reuse of waste materials. This is hinged on environmental considerations related to increased scarcity of natural resources, increasing cost of landfill in most countries (Arulrajah et al, 2011; Oluremi et al., 2012; Kumpala et al, 2013; Oluremi et al, 2016a). The application of agro and industrial wastes in the stabilization of soil is an environmentally friendly method of disposal of large amounts of substances that would have constituted pollution to land, water and air. Some industrial and agricultural wastes which though are seeing as wastes have been discovered to possess potential for improving soil properties. The agricultural and industrial wastes that possessed pozzolanic properties and which have been studied are Corn cob ash (Adesanya and Raheem, 2009), Waste burnt clay (Syagga et al, 2001), Hair fibre (Adedokun et al, 2016), Saw dust ash (Raheem et al, 2012, Raheem et al, 2017), Waste wood ash (Osinubi et al., 2017; Oluremi et al., 2017), Coconut husk ash (Oluremi et al., 2012), Coconut shell ash (Oluremi et al, 2016b) Corn stalk ash (Raheem et al, 2017) and Corn husk ash (Nazir et al, 2012; Peter and Emmanuel, 2013). Some of these wastes such as fly ash, plastics, rice husk ash, cement kiln dust, pulp and paper waste are not only being produce excessively but also hazardous and creating disposal problems (Trivedi etal., 2013; Oluremi et al, 2016a).

Cement kiln dust (CKD) is a by-product of cement manufacturing processes emanating from unreacted raw feed, partially calcined feed and clinker dust, free lime, compounds of alkalis, sulphates, halides and other volatile compounds (Abeln et al, 1990; Sreekrishnavilasam and Santagata, 2006). It is a gray-whitish powdery substance with particle size ranging between 5 and $100 \mu \mathrm{m}$ and majorly approximately $80 \%$ by mass of the CKD has diameter

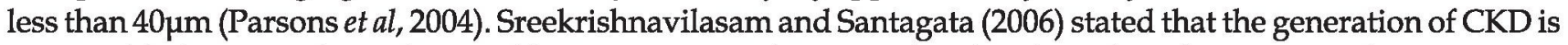
responsible for a significant financial loss in cement industries related to the value of raw materials, processing, energy usage, dust collection, storage and disposal. Although CKD has the potential for reuse in many different ways, the best way of reusing it is to recycle it in cement making process which always is not feasible in some kiln facilities (Siddique, 2006; Siddique, 2014). According to EPA (1993), approximately 60-67 (8-8.4 million tons) percent of the total CKD generated is reused in USA. While the bulk of CKD is recycled into the cement manufacturing process, a significant amount estimated to be up to $4.6 \mathrm{million}$ metric tons and which corresponds to approximately $4.2 \%$ of the raw materials used for the production of cement is generated as waste (Parsons et al, 2004; Oluremi et al, 2016a). The major method for disposing CKD is by dumping on a dump site. This may be done in piles on unused areas or may be transported to abandoned sections from which raw materials have been extracted (Abd El-Aleem et al, 2005). Several studies (Bhatty et al, 1996; Miller and Azad, 2000; Miller et al, 2003; Medjo and Riskowiski, 2004; Osinubi and Moses, 2011) had investigated the use of CKD in stabilizing and solidifying subgrade pavement material and contaminated soil. In fact, it is advantageous over lime in soil 
stabilization since it is not only effective for improving soils strength, but also helps in minimizing work time and cost (Miller and Zaman, 2000; Siddique, 2006; Siddique, 2014). However, data on the effect of CKD on the geotechnical properties of predominantly clay soil is very scarce.

This study therefore investigated the effects of cement kiln dust as a possible stabilizing additive for improving the geotechnical properties of clay soil. The positive results of which will promote it as one of the ideal means of disposing off CKD as residual waste in the environment thereby forestalling health and environmental challenges associated with it.

\section{Materials and Method}

Soil

The clay soil used for this study was collected as disturbed samples from clay deposit at Ede in Ede North Local Government Area, Osun State, which lies within the geographical coordinates of $7^{0} \mathrm{~N}$ and $4^{0} \mathrm{E}$. The soil sample was air-dried, pulverized and sieved through BS sieve No $4(4.63 \mathrm{~mm})$ prior to its use.

\section{Cement Kiln Dust}

The cement kiln Dust (CKD) used was a product of long wet kiln which was collected from Lafarge Cement Factory, Ewekoro, Ogun State, Nigeria. The specimen was sieved through BSSieve No. $200(75 \mu \mathrm{m})$ and kept in an air and water-tight container to prevent it from gaining moisture and contamination. No test was carried out on the CKD used to determine its oxides composition however; the chemical composition of CKD from different operation sources as compiled by Oluremi et al., (2016b) is given in table 1 .

\section{Sample Preparation}

The clay soil samples were mixed with varying percentages of cement kiln dust $(0,2,4,6,8$ and $10 \%$ by mass of soil sample). Particle size analysis, specific gravity, consistency limits, compaction and California bearing ratio tests were conducted on the stabilized soil specimens in accordance with the procedures outlined in BS1377 (1990) and BS 1924 (1990). Two compactive energy levels, [British Standard light (BSL) and West African Standard (WAS)], were used to determine the moisture-density relationships of the prepared samples. BSL is an energy level obtained by using 27 blows of $2.5 \mathrm{~kg}$ rammer dropped from $300 \mathrm{~mm}$ height on each layer of soil specimen placed in three layers inside $1000 \mathrm{~cm}^{3}$ mould while WAS is a compactive effort exerted by using 10 blows of $4.5 \mathrm{~kg}$ rammer from $450 \mathrm{~mm}$ height on each layer of soil specimen placed in five layers inside $1000 \mathrm{~cm}^{3}$ mould. Specimens of natural soil and soil-CKD mixtures were prepared by mixing predetermined quantities of the clay soil and CKD with appropriate quantity of water inside a tray and then compacted at selected and desirable energy level to obtain its moisture-density relationship according to BS1924 (1990).

Table 1:

\begin{tabular}{ccccc}
\hline Constituents & $\begin{array}{c}\text { Long-wet kiln } \\
\text { (\% by weight) }\end{array}$ & $\begin{array}{c}\text { Long-dry kiln } \\
\text { (\% by weight) }\end{array}$ & $\begin{array}{c}\text { Alkali by-pass from } \\
\text { preheater/precalciner } \\
\text { (\% by weight) }\end{array}$ & $\begin{array}{c}\text { Typical Type I } \\
\text { Portland Cement } \\
\text { (\% by weight) }\end{array}$ \\
\hline $\mathrm{SiO}_{2}$ & 15.02 & 9.64 & 15.23 & 20.5 \\
$\mathrm{Al}_{2} \mathrm{O}_{3}$ & 3.85 & 3.39 & 3.07 & 5.4 \\
$\mathrm{Fe}_{2} \mathrm{O}_{3}$ & 1.88 & 1.10 & 2.00 & 2.6 \\
$\mathrm{CaO}$ & 41.01 & 44.91 & 61.28 & 63.9 \\
$\mathrm{MgO}$ & 1.47 & 1.29 & 2.13 & 2.1 \\
$\mathrm{SO}$ & 6.27 & 6.74 & 8.67 & 3.0 \\
$\mathrm{Na}_{2} \mathrm{O}$ & 0.74 & 0.27 & 0.34 & $<1$ \\
$\mathrm{~K}_{2} \mathrm{O}$ & 2.57 & 2.40 & 2.51 & $<1$ \\
Free lime (CaO) & 0.85 & 0.52 & 27.18 & $0-3$ \\
\hline Loss on Ignition (LOI) & 25.78 & 30.24 & 4.48 & \\
\hline
\end{tabular}

\section{Results and Discussion}

\section{Specific gravity}

The variation of the specific gravity of the clay soil with the increasing contents of cement kiln dust (Figure 1) results indicated a significant increase in the specific gravity of the soil from 2.61 for the natural soil to 2.91 for $10 \%$ addition of the CKD. This suggests that cement kiln dust can be effective used to increase the density of the soil thereby leading a significant improvement in soil strength. 


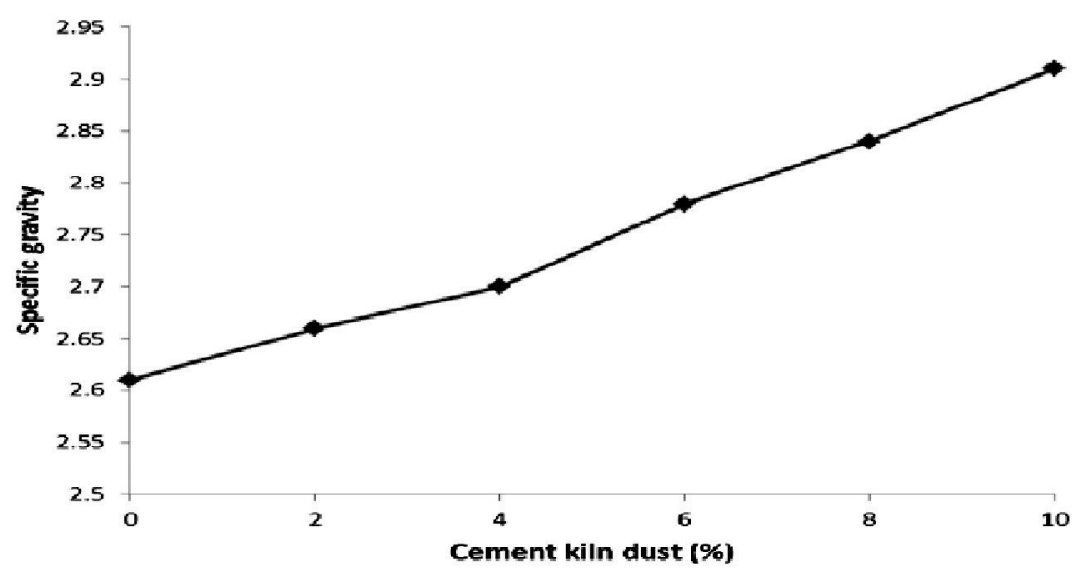

Figure 1: Variation of specific gravity with cement kiln dust

\section{Sieve Analysis}

The percentage of the soil samples passing sieve No. $200(0.075 \mathrm{~mm})$ was $44.6 \%$ (Figure 2$)$ which is greater than $35 \%$ specified for any material to be used as either subbase or base course. The soil is therefore unfit for road construction, but the result is an indication of its usefulness only for the construction liner and cover in landfill (Bensonetal., 1994; Mateo, 2008).

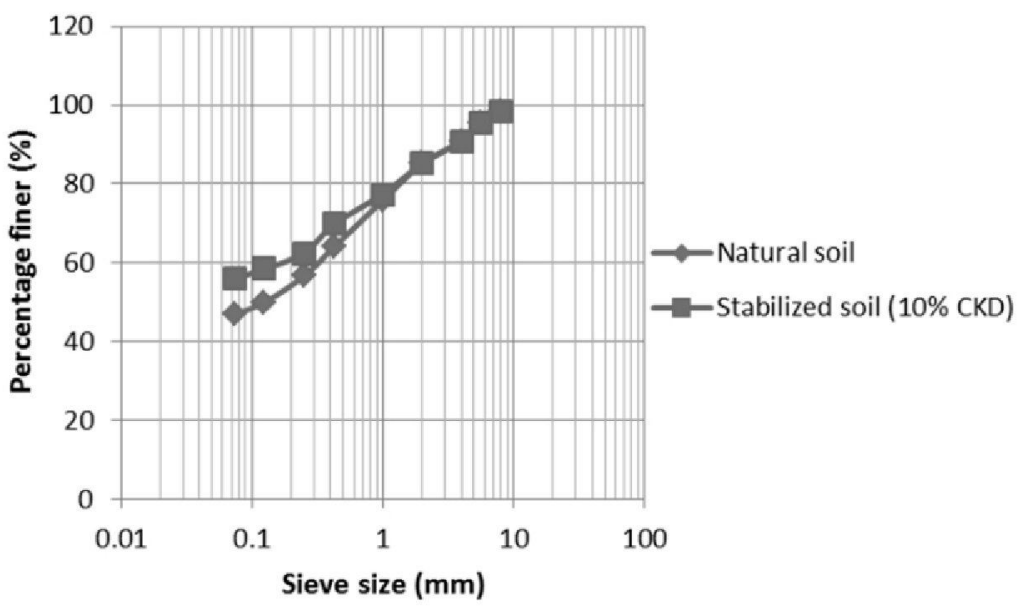

Figure 2: Particle size distribution curve for the natural and stabilized soil

\section{Consistency Limits}

The effects of the cement kiln dust on the consistency limits of the Ede clay is shown in Figure 3 . The liquid limit and plastic limit of the soil samples ranged from 41.89 to $53.83 \%$ and 25.35 to $34.59 \%$ respectively. The plasticity index of the clay sample showed a slight increase in value from 0-6\% addition of CKD but decreased significantly, with the further addition of the additive. The plasticity indices were $16.54 \%$ and $8.48 \%$ at 0 and $10 \%$ addition of the cement kiln dust, respectively. These results showed that CKD can be used to increase the liquid and plastic limits and can also be used to reduce the plasticity index of the clay soil. The cementitious nature of CKD helps in improving the soil relative to its plasticity thereby resulting in more of coarse aggregates which is advantageous to road construction works. These results are also in agreement with the previous studies of (Miller and Zaman, 2000; Waters and Schwieger, 2002; Parsons et al, 2004). 


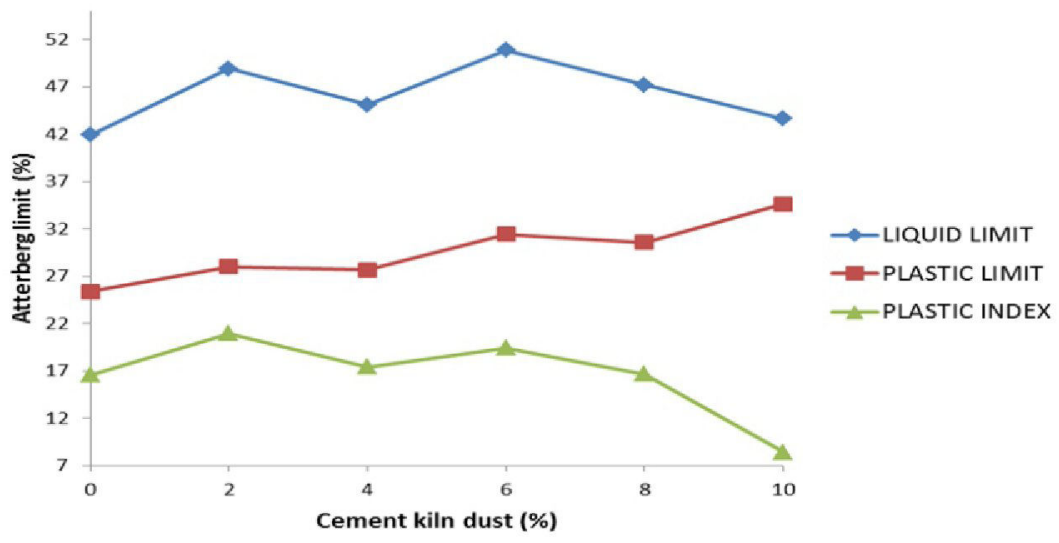

Figure 3: Effects of cement kiln dust on the consistency limits of Ede clay

Base on the particle size distribution and the consistency limits of the Ede clay soil, it is classified as A-7 soil which is unsuitable for the construction of road. However, the treatment of the soil sample with $10 \%$ CKD improved the properties of the soil from A-7 groups to A-5 groups which thereby makes the stabilised sample more suitable for subgrade than the natural soil.

\section{Compaction}

The influence of the cement kiln dust on the compaction characteristics of the clay soil sample indicated that Maximum Dry Density (MDD) and Optimum Moisture Content (OMC) of the soil samples increased continuously with increasing contents of the CKD from 0 to $8 \%$ (Figure 4) while the MDD decreased with further addition of CKD. Similarly, compaction characteristics clay soil increased with increase in the compaction energy levels from British Standard Light (BSL) and West African Standard (WAS). The maximum dry density of the natural soil sample increased from 1.72 to $1.84 \mathrm{~g} / \mathrm{m}^{3}$ and 1.76 to $1.85 \mathrm{~g} / \mathrm{m}^{3}$ at $8 \%$ CKD for BSL and WAS, respectively. This is an indication that density of the soil increase with increasing compactive energy level. In addition, CKD can be used to increase the density of the clay soil sample up to $8 \%$ replacement of the soil sample. This is quiet expected because CKD acts as binding medium between the micro-sized clay particles forming macro-sized particle of higher density and compactness which is primarily due to the high reactivity as a result of high free lime content in CKD (Sreekrishnavilasam and Santagata, 2006).

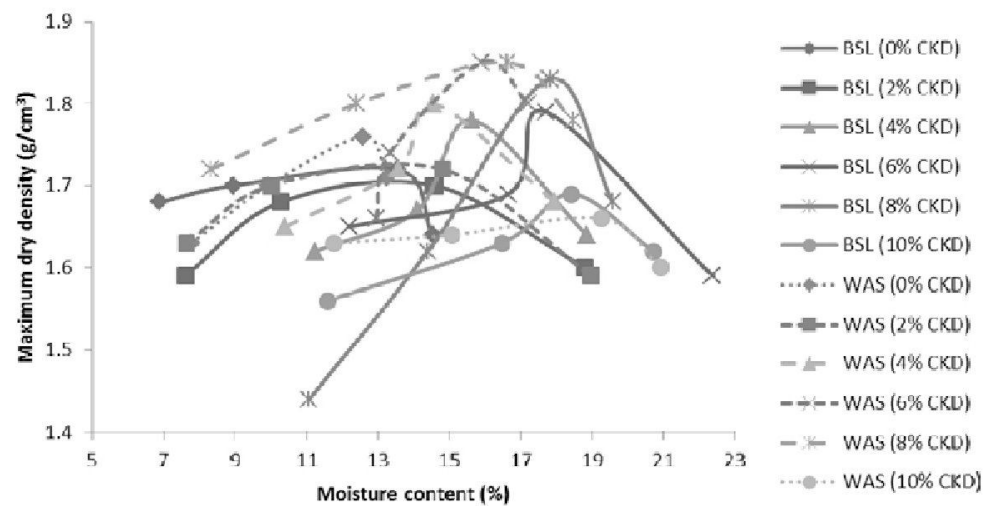

Fig.4: Effects of cement kiln dust on the compaction characteristics of the clay soil

\section{California bearing ratio}

The behaviour of California bearing ratio, $C B R$ under soaked and unsoaked conditions with different percentages of cement kiln dust is presented in Figure 5. The CBR values for both soaked and unsoaked soil conditions increased continuously with increase in CKD content. The ranges of CBR values for $0-10 \%$ CKD addition are 9 $17 \%$ and $17-35 \%$ for soaked and unsoaked soil conditions, respectively using WAS as energy level. This increase in the strength is due to the cementation of the clay soil particles by the formation of cementitous materials between the liberated lime from CKD and the silica and alumina present within the soil (Sreekrishnavilasam and Santagata, 2006). This gives indication that cement kiln dust can be effectively used to improve the CBR value of the Ede clay. At $10 \%$ cement contents, this clay soil can be utilized as a subgrade material. 


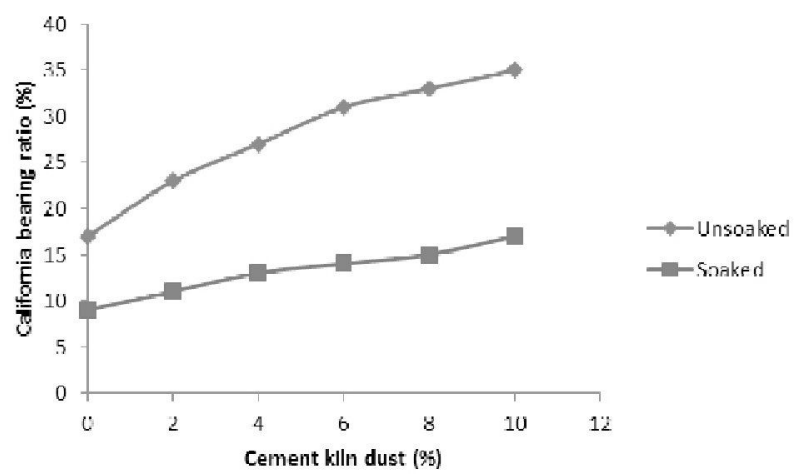

Figure 5: Effects of cement kiln dust on the California bearing ratio of Ede clay

\section{Conclusion}

The effects of cement kiln dust on the geotechnical properties of clay have been carried out in accordance with BS 1377 (1990) and BS 1924 (1990). The following conclusions were drawn from the results of the various soil tests conducted.

i. The treatment of the soil sample with $10 \%$ cement kiln dust improved the classification of the soil from A-7 groups to A-5 groups which thereby makes the stabilised sample more suitable for subgrade than the natural soil. The specific gravity of the soil sample increased with increasing contents of CKD.

ii. Addition of cement kiln dust increased the liquid limit and plastic limit but decreased the plasticity index of the clay soil thereby improving its workability.

iii. The Maximum Dry Density (MDD) of the soil sample increased with the addition of CKD from 0 to $8 \%$, but further addition of this additive leads to decrease in MDD. Similarly, its OMC increased continuously up to $10 \%$ CKD.

iv. The California Bearing Ratio (CBR) of the soil increased continuously with increasing CKD contents both for unsoaked and soaked samples.

Based on the results of this study, $8 \%$ cement kiln dust content yielded the best results in terms of strength, stability and workability and it is therefore recommended for improving the strength characteristics of the clay soil.

\section{References}

Abd El-Aleem, S., Abd-El-Aziz, M.A., Heikal, M. and El Didamony, H. (2005) Effect of cement kiln dust substitution on Chemical and physical properties and compressive Strength of portland and slag cements, The Arabian Journal for Science and Engineering, 30, (2B): 263-273.

Abeln, D.L., Hastings, R.J., Scxhreiber, R.J., and Yonley, C. (1990). Detailed Illustration of Contingent Management Practices for Cement Kiln Dust. Research and Development Bulletin, SP115T, Portland Cement Association, Skokie, IL.

Adedokun, S. I., Ajamu, S. O. and Aderinto, H. O. (2016). Effect of Synthetic Hair Fibre Additions on the Strength Characteristics of Concrete, USEP: Journal of Research in Civil Engineering (RICE), 13 (2): $928-939$

Adesanya, D.A. and Raheem, A. A. (2009) Development of corn cob ash blended cement, Construction and Building Materials, 23 (4):347-352. doi:10.1016/j.conbuildmat.2007.11.013

Arulrajah A., Piratheepan J., Aatheesan T. and Bo M.W. (2011) Geotechnical properties of recycled crushed brick in pavement applications. J. Mater. Civil. Eng. 23 (10):1444-52.

Benson, C. H., Zhai, H. and Wang, X. (1994) "Estimating hydraulic conductivity of compacted clay liners." Journal of Geotechnical Engineering, ASCE 120(2):366-387.

Bhatty, J.I., Bhattacharja, S., and Todres, H.A. (1996) Use of Cement Kiln Dust in Stabilizing Clay Soils, Research \& Development Bull, RP343, Portland Cement Assoc., Skokie, IL.

EPA, U.S. Environmental Protection Agency. (1993) Report to congress on cement kiln dust, EPA-530-R-94-001.

Kumpala, A., Horpibulsuk, S., Chinkullijniwat, A. and Shen, S. (2013) Engineering properties of recycled Calcium Carbide Residue stabilized clay as fill and pavement materials Construction and Building Materials, 46: 203-210

Mateo, R. A. J. (2008). Evaluation of the Performance of Soil Liners using the Mechanics of Saturated and Unsaturated soils. Published Master of Engineering Thesis, Civil Engineering Department, University of Ottawa, Ottawa, Canada 


\section{K1N6N5.}

Medjo E. and Riskowiski, G. (2004) A Procedure for Processing Mixture of Soil, Cement and Sugar cane Baggash. Agricultural Engineering International. The Journal of Scientific Research and Development. Manuscript BC 990. Vol.1 - 5.

Miller G. A. and Zaman M. (2000) Field and laboratory evaluation of cement kiln dust as a soil stabilizer. Transportation Research Record, No. 1714: 25-32.

Miller, G. A., and Azad, S. (2000) Influence of Soil Type on Stabilization with Cement Kiln Dust. Construction and Building Materials 14 (2), 89-97.

Miller, G. A., Zaman, M., Rahman, J., and Tan, K.N. (2003) Laboratory and Field Evaluation of Soil Stabilization Using Cement Kiln Dust. Final Report, No. ORA 125- 5693, Planning and Research Division, Oklahoma Department of Transportation.

Nazir, M, Abeyruwan, H and Manroof, M. (2012) Waste ash pozzolans reactivity and suitability for use in concrete, Retrieved September 18, 2014 fromhttp://www.ricehuskashpozzolanic-materialforpdf

Oluremi, J. R, Yohanna, P., Ishola, K, Yisa, G. L, Eberemu, A. O., Ijimdiya, S. T. and Osinubi, K. J. (2017) Plasticity of Lateritic Soil Admixed with Selected Admixtures accepted for publication in Environmental Geotechnics, Institute of Civil Engineering (ICE), United Kingdom. http://dx.doi.org/10.1680/jenge.15.00085

Oluremi, J. R., Osuolale, O. M., Adeoye, T. T. and Akingbade, A. A. (2016b) Strength Development in Lateritic Soil Stabilised with CoconutShell Ash for Highway Pavement Construction, Innovative Systems Design and Engineering, 7 (11): 49-56.

Oluremi, J.R. Adedokun, S. I. and Osuolale, O. M. (2012) Stabilization of Poor Lateritic Soils with Coconut Husk Ash, International Journal of Engineering Research \& Technology (IJERT) 1 (8): 1-9, www.ijert.org

Oluremi, J.R., Siddique, R. and Adeboje, E.P. (2016a). Stabilization Potential of Cement Kiln Dust Treated Lateritic Soil, International Journal of Engineering Research in Africa, 23:52-63.

Osinubi, K. J. and Moses, G. (2011). "Compacted foundry sand treated with bagasse ash as hydraulic barrier material." In: Advances in Geotechnical Engineering. Edited by Jie Han and Daniel E. Alzamora, Geotechnical Special Publication, GSP 211,pp. 915-925.

Osinubi, K. J., Oluremi, J. R., Eberemu, A. O., and Ijimdiya, S. T. (2017) Chemical Interaction compatibility of Lateritic Soil stabilized with Wood waste ash with municipal solid waste leachate. Wastes and Resources Management, 170 (WR3+4): 128-138. Institute of Civil Engineering (ICE) http://doi.org/10.1680/jwarm.17.00012

Parsons, R. L., Kneebone, E. and Milburn, J. P. (2004) Use of Cement Kiln Dust for Subgrade Stabilization, Kansas Department of Transportation, Division of Operations, Bureau of Materials and Research, Topeka, Kansas.

Peter, K.Y and Emmanuel, A. (2013). Enhancing the Properties of Soil Bricks by Stabilizing with Corn Husk Ash, Civil and Environmental, 3(11): 2224-5790.

Raheem, A. A., Olasunkanmi, B. S. and Folorunsho, C. S. 2012. Saw Dust Ash as Partial Replacement for Cement in Concrete, Organization, technology and management in construction - an international journal, 4(2), 474-480. DOI 10.5592/otmcj.2012.2.3.

Raheem, A.A., Adedokun, S.I., Adeyinka, E.A. and Adewole, B.V. (2017) Application of Corn Stalk Ash as Partial Replacement for Cement in the Production of Interlocking Paving Stones, International Journal of Engineering Research in Africa, 30: 85-93

Raheem, A.A., Adedokun, S.I., Ajayi, B.R., Adedoyin, O.A and Adegboyega, B.O. (2017) Application of Saw Dust Ash as Partial Replacement for Cement in the Production of Interlocking Paving Stones, International Journal of Sustainable Construction Engineering and Technology, 8(1):1-11.

Siddique, R. (2006). Utilization of cement kiln dust (CKD) in cement mortar and concrete - an overview. Resources, Conservation and Recycling 48:315-338

Siddique, R. (2014) Utilization of industrial by-products in concrete. In 2nd International Conference on Sustainable Civil Engineering Structures and Construction Materials 2014 (SCESCM 2014) Procedia Engineering 95335 - 347. doi:10.1016/j.proeng.2014.12.192

Sreekrishnavilasam, A. and Santagata, M. C. (2006) Development of criteria for the utilization of Cement kiln dust (ckd) in highway infrastructures. Joint Transportation Research Program, School of Civil Engineering, Purdue University and Indiana Department of Transportation and the U.S. Department of Transportation, Project No. C-36-50Y.

Syagga P.M, Kamau S.N., Waswa-Sabuni B. and Dulo S.O. 2001. Potentials of using waste burnt clay as a pozzolanic material in Kenya. J Discovery Innovat, 13(3/4):114-8.

Trivedi, J. S., Nair, S. and Iyyunni, C. (2013) Optimum Utilization of Fly Ash for Stabilization of Sub-Grade Soil using Genetic Algorithm Procedia Engineering 51,250 - 258. doi: 10.1016/j.proeng.2013.01.034

Waters, R.D., and Schwieger, K.J. (2002) Cement Kiln Dust Stabilization Study. Terrracon. Project 01021414. Wichita, Kansas. 4 p. 